\title{
Nickel catalysts for internal reforming in molten carbonate fuel cells
}

\author{
R.J. Berger ${ }^{\mathrm{a}, *, 1}$, E.B.M. Doesburg ${ }_{b}^{\mathrm{a}, 2}$, J.G. van Ommen ${ }^{\mathrm{a}}$, \\ J.R.H. Ross \\ ${ }^{\mathrm{a}}$ Laboratory of Inorganic Chemistry, Materials Science and Catalysis, Faculty of Chemical Technology, \\ University of Twente, Enschede, The Netherlands \\ ${ }^{\mathrm{b}}$ Department of Chemical and Environmental Sciences, University of Limerick, Limerick, Ireland
}

Received 24 January 1996; accepted 26 February 1996

\begin{abstract}
Natural gas may be used instead of hydrogen as fuel for the molten carbonate fuel cell (MCFC) by steam reforming the natural gas inside the MCFC, using a nickel catalyst (internal reforming). The severe conditions inside the MCFC, however, require that the catalyst has a very high stability. In order to find suitable types of nickel catalysts and to obtain more knowledge about the deactivation mechanism(s) occurring during internal reforming, a series of nickel catalysts was prepared and subjected to stability tests at $973 \mathrm{~K}$ in an atmosphere containing steam and lithium and potassium hydroxide vapours. All the catalysts prepared showed a significant growth of the nickel crystallites during the test, especially one based on $\alpha-\mathrm{Al}_{2} \mathrm{O}_{3}$ and a coprecipitated $\mathrm{Ni} / \mathrm{Al}_{2} \mathrm{O}_{3}$ sample having a very high nickel content. However, this growth of nickel crystallites only partially explained the very strong deactivation observed in most cases. Only a coprecipitated nickel/alumina catalyst with high alumina content and a deposition-precipitation catalyst showed satisfactory residual activities. Addition of magnesium or lanthanum oxide to a coprecipitated nickel/alumina catalyst decreased the stability.

Adsorption and retention of the alkali was the most important factor determining the stability of a catalyst in an atmosphere containing alkali hydroxides. This is because the catalyst bed may remain active if a small part of the catalyst bed retains all the alkali.
\end{abstract}

Keywords: Molten carbonate fuel cell; Nickel; Steam reforming; Lithium; Potassium; Deactivation

\footnotetext{
* Corresponding author. Tel. (+31-40) 2473589, fax. (+31-40) 2446653, e-mail tgtcrb@chem.tue.nl.

Present address: Eindhoven University of Technology, LCT, P.O. Box 513, 5600 MB Eindhoven, The Netherlands.

${ }^{2}$ Present address: ECN, Materials Science, Petten, The Netherlands.
} 


\section{Introduction}

The molten carbonate fuel cell (MCFC) is likely to be commercialised soon (Hirschenhofer [1]). This cell operates at about $923 \mathrm{~K}$ and requires hydrogen as fuel; the hydrogen is usually obtained from natural gas (according to Eq. (1)) or from naphtha by steam reforming in a separate unit (external reforming).

$$
\mathrm{CH}_{4}+\mathrm{H}_{2} \mathrm{O} \leftrightharpoons 3 \mathrm{H}_{2}+\mathrm{CO}
$$

Another possible source of hydrogen is the reforming of natural gas within the fuel cell (internal reforming). The catalyst particles may then be positioned in the anode gas compartment within the corrugations of the plate separating the anode from the cathode of the next cell of the stack, see Fig. 1.

Internal reforming has attracted considerable attention because it offers several extra advantages in comparison with external reforming: (i) the all-over efficiency of the fuel cell increases due to the consumption of the heat evolved in the cell reaction by the endothermic reforming reaction; this heat consumption is about half of the heat production caused by the current flowing through the internal resistances and by the reversible energy losses in the MCFC [2]; (ii) the water required for the steam-reforming reaction is partially provided by the fuel cell reaction; (iii) there is a more evenly distributed supply of hydrogen over the anode compartment; and (iv) the equilibrium conversion in the steam-reforming reaction (Eq. (1)) is further to the right due to the in situ consumption of hydrogen.

Internal reforming, however, requires substantial adaptation of the MCFC construction to allow the catalyst to be incorporated. Of even more importance is that the catalyst is gradually affected by alkali carbonate originating from the electrolyte, a mixture of $62 \mathrm{~mol} . \% \mathrm{Li}_{2} \mathrm{CO}_{3}$ and $38 \mathrm{~mol} . \% \mathrm{~K}_{2} \mathrm{CO}_{3}$ [3,4]. Small amounts of this electrolyte gradually migrate towards the catalyst during operation.

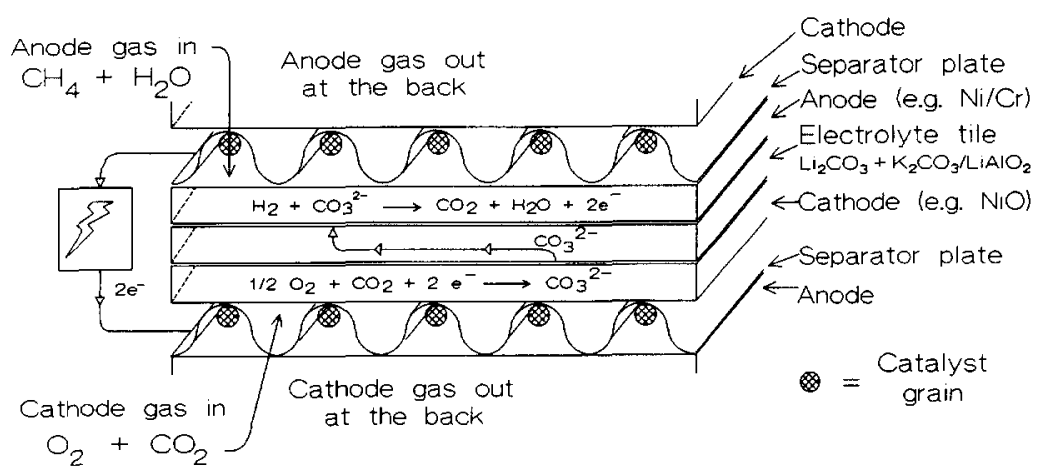

Fig. 1. Cross-sectional view of the repeating unit of a molten carbonate fuel cell stack containing catalyst for internal reforming. 
Research on the suppression of deactivation of internal reforming catalysts has mainly been concerned with nickel supported on alkali-resistant supports such as $\mathrm{MgO}$ [3-9], $\gamma-\mathrm{LiAlO}_{2}$ [3,7] and $\alpha-\mathrm{LiAlO}_{2}$ [8]. The majority of these publications have shown successful results with these catalysts; however, the times of operation were in many cases rather short and/or the test conditions were less severe than normally encountered under practical conditions.

Because the predominating deactivation mechanism under MCFC conditions is still not clear and mechanisms other than reaction of the support with alkali may be more important, it cannot be concluded that nickel catalysts based on supports not having a high resistance to alkalis do not have better stabilities.

In another paper [10] it is shown that the alkali in the MCFC is predominantly transported from the molten mixture of alkali carbonates towards the catalyst through the vapour phase as $\mathrm{LiOH}$ and $\mathrm{KOH}$. All aluminium-containing samples (including $\alpha-\mathrm{Al}_{2} \mathrm{O}_{3}$ ) were found to take up alkali hydroxide from the gas phase very rapidly; in contrast, $\mathrm{Ni} / \mathrm{MgO}$ and $\mathrm{Ni} / \mathrm{SiO}_{2}$ samples hardly took up any alkali hydroxide from the gas phase even though these samples sintered strongly in the presence of the alkali hydroxide vapour.

This paper is concerned with the effect of alkali hydroxide vapour on the steam-reforming activity and other characteristics of different nickel catalysts and with determining the most important causes of deactivation. The deactivation due to deposition of alkali hydroxide vapour may occur in several different ways: (i) pore filling; (ii) pore plugging; (iii) coverage of the surface of the nickel crystallites; (iv) decrease of the specific activity; and (v) enhanced sintering of the nickel crystallites and/or the support. Once the alkali hydroxide is present on the catalyst surface, it can be retransformed to the corresponding alkali carbonate or be converted into other alkali compounds. In order to gain a greater understanding of the deactivation mechanism, a series of stability tests was performed in which alkali hydroxide vapour was slowly added to the catalyst and the steam-reforming activity of the catalyst was measured continuously. The deactivated catalysts were characterised using several techniques.

\section{Experimental}

\subsection{Catalyst preparation}

Two catalysts were prepared by impregnation, using the incipient wetness technique with $\gamma-\mathrm{Al}_{2} \mathrm{O}_{3}$ and $\alpha-\mathrm{Al}_{2} \mathrm{O}_{3}$ as supports. The $\mathrm{Ni} / \gamma-\mathrm{Al}_{2} \mathrm{O}_{3}$ sample denoted hereafter as $\mathrm{I}-\gamma \mathrm{Al}$ was prepared by vacuum impregnation of $10 \mathrm{~g}$ of $\gamma-\mathrm{Al}_{2} \mathrm{O}_{3}$ extrudates (Akzo alumina $000-1.5 \mathrm{E}$, pore volume $=0.46 \mathrm{~cm}^{3} \mathrm{~g}^{-1}$, BET surface area $=188 \mathrm{~m}^{2} \mathrm{~g}^{-1}$ ) at $323 \mathrm{~K}$ with ca. $4 \mathrm{~mol} \mathrm{dm} \mathrm{dm}^{-3}$ nickel nitrate. The $\mathrm{Ni} / \alpha-\mathrm{Al}_{2} \mathrm{O}_{3}$ sample, denoted as $\mathrm{I}-\alpha \mathrm{Al}$, was prepared by four-fold impreg- 
nation of $10 \mathrm{~g}$ of Raschig rings of $\alpha-\mathrm{Al}_{2} \mathrm{O}_{3}$ (Dycat, 26/RMS E002.B, pore volume $=0.28 \mathrm{~cm}^{3} \mathrm{~g}^{-1}$, BET surface area $=0.22 \mathrm{~m}^{2} \mathrm{~g}^{-1}$ ) with ca. $3 \mathrm{~mol} \mathrm{dm}-3$

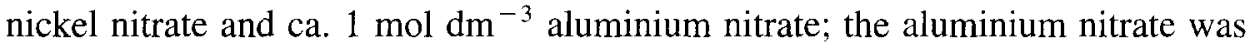
co-impregnated in order to improve the resistance to sintering [11]. The material was dried at $393 \mathrm{~K}$ and calcined at $573 \mathrm{~K}$ in air between each of the impregnation steps.

A series of catalysts containing various combinations of $\mathrm{Ni}, \mathrm{Al}, \mathrm{Mg}$ and $\mathrm{La}$ was prepared by coprecipitation using the constant $\mathrm{pH}$ method [12,13], yielding about $10 \mathrm{~g}$ of catalyst, using the metal nitrates and potassium carbonate as base. Each coprecipitate was filtered off and washed once thoroughly with $1 \mathrm{dm}^{3}$ of hot deionised water $(353 \mathrm{~K})$; it was finally dried in an oven at $353 \mathrm{~K}$ overnight. The coprecipitated catalysts are indicated by the prefix $\mathrm{C}$, followed by the ratios of the metal ions used.

The deposition-precipitation was performed according to the method as described by Schaper et al. [14,15]. This catalyst is denoted hereafter by DP.

The catalyst precursors were calcined in a tube furnace in flowing air ( 200 $\mathrm{cm}^{3} \mathrm{~min}^{-1}$ ), using a heating rate of $2 \mathrm{~K} \mathrm{~min}^{-1}$ up to a final temperature of 723 , 773,873 , or $1073 \mathrm{~K}$, this being maintained for $5 \mathrm{~h}$. Reduction was then carried out in the same tube furnace in $170 \mathrm{~cm}^{3} \min ^{-1}$ of $70 \% \mathrm{H}_{2}$ in $\mathrm{N}_{2}$ using a heating rate of $2 \mathrm{~K} \mathrm{~min}^{-1}$ to a final temperature of $973 \mathrm{~K}$, this being maintained for $5 \mathrm{~h}$. After cooling to room temperature and flushing with nitrogen, the samples were passivated in $0.75 \% \mathrm{O}_{2}$ in $\mathrm{N}_{2}\left(200 \mathrm{~cm}^{3} \mathrm{~min}^{-1}\right)$ for at least $5 \mathrm{~h}$.

The chemical compositions of the catalysts after calcination and reduction calculated from the atomic absorption spectrometry analyses are shown in Table 1 .

The powders prepared by coprecipitation were pressed isostatically at 4000 bar. The resulting lumps and also the extrudates and the Raschig rings were crushed and sieved to give sieve fractions with particle diameters between 0.125 and $0.3 \mathrm{~mm}$ for use in the activity and stability measurements.

Table 1

Catalyst composition in wt.\% (after reduction)

\begin{tabular}{|c|c|c|c|c|c|}
\hline Catalyst & $\mathrm{Ni}$ & $\mathrm{Al}$ & $\mathrm{La}$ & $\mathrm{Mg}$ & $\mathrm{K}$ \\
\hline $\mathrm{I}-\alpha \mathrm{Al}$ & 14.7 & n.d. & - & - & - \\
\hline $\mathrm{I}-\gamma \mathrm{AI}$ & 13.0 & n.d. & - & - & - \\
\hline $\mathrm{C}-\mathrm{Ni}_{3} \mathrm{Al}$ & 78.7 & 11.2 & - & - & 0.06 \\
\hline $\mathrm{C}-\mathrm{NiAl}_{3}$ & 26.8 & 38.7 & - & - & 0.09 \\
\hline $\mathrm{C}-\mathrm{NiAl}_{2.5} \mathrm{La}_{0.5}$ & 18.6 & 24.0 & 7.9 & - & 0.03 \\
\hline $\mathrm{C}-\mathrm{NiAl}_{2} \mathrm{Mg}$ & 30.8 & 28.7 & - & 9.0 & 0.09 \\
\hline $\mathrm{C}-\mathrm{NiMg}_{3}$ & 29.4 & - & - & n.d. & n.d. \\
\hline DP & 19.4 & 40.6 & - & - & 0.63 \\
\hline
\end{tabular}

n.d.: not determined. 


\subsection{Stability tests}

All the stability tests were performed at $973 \mathrm{~K}$ and ca. $1.2 \mathrm{bar}$. The temperature of $973 \mathrm{~K}$ is $50 \mathrm{~K}$ higher than the operation temperature of the $\mathrm{MCFC}$ and was chosen to allow comparison of the different materials within a relatively short period of time.

The reactor configuration used (Fig. 2) was designed to prevent surface creep of alkali from the impregnated $\mathrm{LiAlO}_{2}$ towards the catalyst. It consisted of two alumina tubes (each of internal diameter $0.4 \mathrm{~cm}$ and length $32.5 \mathrm{~cm}$ ) fitted inside a quartz tube (length $66 \mathrm{~cm}$, internal diameter $0.9 \mathrm{~cm}$ ) there being a distance of $1.0 \mathrm{~cm}$ between the alumina tubes. A short packed bed containing $200 \mathrm{mg}$ of $\mathrm{LiAlO}_{2}$ grains (mean pore diameter $0.4 \mu \mathrm{m}$, pore volume $0.41 \mathrm{~cm}^{3}$ $\mathrm{g}^{-1}$, grain size 0.3-0.6 mm) impregnated with $\mathrm{Li}_{2} \mathrm{CO}_{3}+\mathrm{K}_{2} \mathrm{CO}_{3}$ (molar ratio $62: 38 ; 9.8$ wt. \% of $\mathrm{K}$ ) between two alumina wool plugs of about $5 \mathrm{mg}$ each (ICI Saffil alumina fibre, calcined at $1473 \mathrm{~K}$ for $3 \mathrm{~h}, S_{\mathrm{BET}}=12 \mathrm{~m}^{2} \mathrm{~g}^{-1}$ ) was positioned in the lower end of the upper alumina tube. About $80 \mathrm{mg}$ of the catalyst (grain size $0.125-0.3 \mathrm{~mm}$ ), held between two separate alumina plugs, was positioned in the upper end of the lower alumina tube. The reactor temperature was controlled by a thermocouple which was positioned between the reactor and the oven wall. In all tests, the reactor was heated and cooled in a $\mathrm{H}_{2} / \mathrm{He}(35 / 65)$ mixture.

Initially, several tests were performed to investigate the rate of alkali transport from the impregnated $\mathrm{LiAlO}_{2}$ grains positioned in the upper alumina tube towards the lower alumina tube. This is necessary for interpretation of the results obtained from the stability tests. $\gamma-\mathrm{Al}_{2} \mathrm{O}_{3}$ was used on the position of the catalyst since it adsorbs alkali vapour strongly [10]. The rate was measured by varying the duration of the test and/or by varying the $\mathrm{CO}_{2}$ content of the gas (and consequently the vapour pressures of the alkali hydroxides [10]), followed

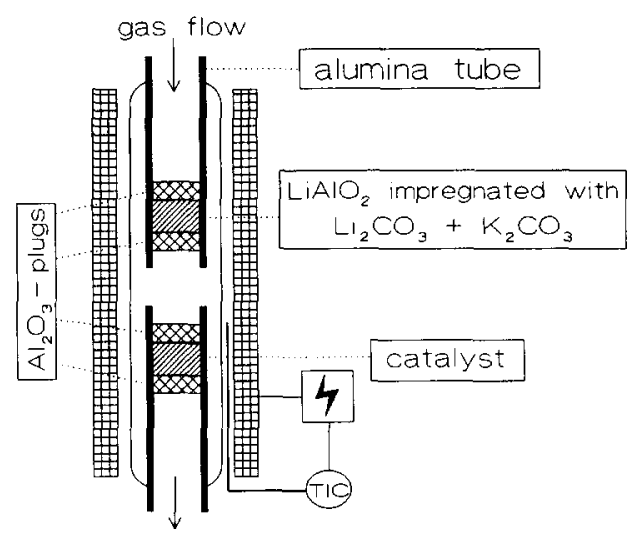

Fig. 2. The reactor used for the stability test in alkali hydroxide vapour (TIC $=$ temperature indicator and controller). 
by chemical analysis of the samples. For this, the following three sets of conditions were used.

Set A: $111 \mathrm{~cm}^{3}(\mathrm{stp}) \mathrm{min}^{-1}$ containing $0.7 \% \mathrm{CH}_{4}, 3.6 \% \mathrm{H}_{2}, 50 \% \mathrm{H}_{2} \mathrm{O}$, and $45.7 \% \mathrm{He}$

Set B: $111 \mathrm{~cm}^{3}(\mathrm{stp}) \mathrm{min}^{-1}$ containing $0.7 \% \mathrm{CH}_{4}, 3.6 \% \mathrm{H}_{2}, 50 \% \mathrm{H}_{2} \mathrm{O}, 0.3 \%$ $\mathrm{CO}_{2}$ and $45.4 \% \mathrm{He}$.

Set C: $50 \mathrm{~cm}^{3}(\mathrm{stp}) \mathrm{min}^{-1}$ containing $4.0 \% \mathrm{CH}_{4}, 20 \% \mathrm{H}_{2}, 20 \% \mathrm{H}_{2} \mathrm{O}, 45 \% \mathrm{CO}_{2}$ and $11 \% \mathrm{He}$.

For the stability experiments, the sets of conditions $\mathrm{A}$ and $\mathrm{C}$ were used. A low concentration of methane was used to prevent a large local temperature drop inside the catalyst bed due to the endothermic steam-reforming reaction. The duration of the tests using Set A was always $161 \mathrm{~h}$. Set $\mathrm{C}$ represents better a typical gas composition for internal reforming than does Set A; however, the presence of $\mathrm{CO}_{2}$ suppresses the evaporation of the alkali to such an extent that very long test durations of $600-880 \mathrm{~h}$ were required. During the tests, the alkali hydroxide vapour was gradually transported with the (downward) gas flow towards the catalyst.

The conversions of methane were measured regularly and the samples of 200 $\mu l$ were analyzed using a gas chromatograph (Varian Type 3300 ) equipped with Porapak $\mathrm{Q}$ columns maintained at $333 \mathrm{~K}$ using $\mathrm{He}$ as carrier gas. The reaction rates ( $r$, moles $\mathrm{CH}_{4} \mathrm{~g}_{\text {cat }}^{-1} \mathrm{~s}^{-1}$ ) were calculated from the conversion of methane $(\alpha)$ assuming plug flow (Dautzenberg [16]) and that the reaction was first order in methane and zero in steam [17-19]:

$$
r=k\left[\mathrm{CH}_{4}\right] \text { where } k=\ln \left(\frac{1}{1-\alpha}\right) \frac{\phi_{\text {tot }}}{m}
$$

where $k$ is the reaction rate constant $\left(\mathrm{m}^{3} \mathrm{~g}_{\text {cat }}^{-1} \mathrm{~s}^{-1}\right),\left[\mathrm{CH}_{4}\right]$ is the methane concentration $\left(\mathrm{mol} \mathrm{m}^{-3}\right), \alpha$ is the methane conversion, $\phi_{\text {tot }}$ is the total gas flow rate at reactor conditions $\left(\mathrm{m}^{3} \mathrm{~s}^{-1}\right)$, and $m$ is the weight of catalyst $(\mathrm{g})$. Values of the rate coefficients above about $200 \cdot 10^{-6} \mathrm{~m}^{3} \mathrm{~g}_{\text {cat }}^{-1} \mathrm{~s}^{-1}$ could not be measured accurately because they were calculated from methane conversions greater than $93 \%$ under which conditions there was significant limitation for diffusion and heat transport.

After the test, the reactor was cooled to room temperature. The impregnated $\mathrm{LiAlO}_{2}$ and the alumina plugs were all weighed to estimate the amount of alkali transported. Several samples were also analyzed chemically for their alkali contents.

\subsection{Characterisation techniques}

X-ray diffraction patterns were recorded with a Philips PW 1710 diffractometer using $\mathrm{CuK} \alpha$ radiation at room temperature and in air. The crystallite sizes 
(D) of the nickel, nickel oxide and several other compounds were estimated by $\mathrm{X}$-ray line broadening (XLB), using the Scherrer equation:

$$
D=\frac{K \lambda}{\beta \cos \theta}
$$

where $K$ is the Scherrer constant, $\lambda$ is the wavelength of the radiation and $\beta$ is the peak width in rad at half the peak maximum. (The peak width was corrected for instrumental line broadening, measured using a sample with nickel crystallites larger than $300 \mathrm{~nm}$, and for broadening caused by $\mathrm{K} \alpha_{1}-\mathrm{K} \alpha_{2}$ division, using the Jones-(b) correction curve [20].) The Scherrer constant $(K)$ used was 1.495 ; this consists of a factor of 0.89 to correct for the fact that the peak width at half maximum instead of the integral peak width is used and another factor of $1.680[21,22]$ to take into account the hemispherical rather than the cubic shape of the nickel crystallites.

Nitrogen adsorption/desorption isotherms at $77 \mathrm{~K}$ were obtained using a Micromeritics ASAP 2400 system. The values of the specific surface areas $\left(S_{\mathrm{BET}}\right)$ were calculated using the BET method while the values of the total pore volume $\left(V_{\mathrm{p}}\right)$ of the pores with radii smaller than $20 \mathrm{~nm}$ (assumed to be cylindrical) were calculated from the adsorption isotherms.

Hydrogen chemisorption for measuring the specific nickel surface areas was carried out using a Micromeritics Pulse Chemisorb 2700 adsorption system. 52.2 $\mu 1$ pulses of mixture of $5.85 \%$ hydrogen in $\operatorname{argon}\left(15 \mathrm{~cm}^{3}(\mathrm{stp}) \mathrm{min}^{-1}\right)$ were passed through about $50 \mathrm{mg}$ of the sample. The total amount of hydrogen adsorbed was determined by measuring with a TCD the amounts of hydrogen remaining in the gas phase after the passage of each pulse. The nickel surface area was calculated by assuming an adsorption stoichiometry of $\mathrm{H}: \mathrm{Ni}=1: 1$ and a number of $1.54 \cdot 10^{19} \mathrm{Ni}$ sites per $\mathrm{m}^{2}$ (Rostrup-Nielsen [17]). The average nickel crystallite sizes were calculated from the metallic surface areas by assuming a hemispherical crystallite shape.

Transmission electron microscopy was carried out using a JEOL 200CX electron microscope operated at $200 \mathrm{kV}$. The TEM specimens were prepared by ultrasonically dispersing powdered samples in ethanol and then applying drops of this suspension onto a carbon film supported on a copper grid.

Auger electron spectroscopy (AES) was used to study the outer surface of the catalyst grains. It was carried out using a Perkin Elmer PHI 600 scanning Auger microprobe. Specimens for Auger analysis were prepared by pressing the catalyst particles into an indium foil. The surface concentrations of the elements were determined by measuring the peak-to-peak distances in the differentiated AES spectra after correction for the relative AES peak intensities. Li could not be detected quantitatively. Depth profiles were obtained by etching the surface with an argon ion beam. A surface etching area of $2 \mathrm{~mm} \times 2 \mathrm{~mm}$ was used; using this area, a reference $\mathrm{Ta}_{2} \mathrm{O}_{5}$ sample was found to be etched at a rate of 12 $\mathrm{nm} \min ^{-1}$. 


\section{Results and discussion}

\subsection{Rate of alkali transport}

The results of the tests to investigate the rate of alkali transport in the test reactor using $\gamma-\mathrm{Al}_{2} \mathrm{O}_{3}$ on the position of the catalyst are shown in Table 2. The $\mathrm{K}$ contents of the impregnated $\mathrm{LiAlO}_{2}$ and the $\gamma-\mathrm{Al}_{2} \mathrm{O}_{3}$ grains are shown as a function of time in Fig. 3. The results show that the vaporisation of alkali from the bed of impregnated $\mathrm{LiAlO}_{2}$ grains occurred rapidly; both the $\mathrm{K}$ and the $\mathrm{Li}$ (not shown) vaporised totally within about $40 \mathrm{~h}$ of operation when the standard gas flow was used. The figure also shows that the rate at which the $\mathrm{K}$ arrived at the $\gamma-\mathrm{Al}_{2} \mathrm{O}_{3}$ was lower than that at which it was transported away from the $\mathrm{LiAlO}_{2}$; it took roughly $100 \mathrm{~h}$ before the rate of increase of alkali concentration in the $\gamma-\mathrm{Al}_{2} \mathrm{O}_{3}$ approached zero. About $50 \%$ of the total amount of $\mathrm{K}$ and only about $5 \%$ of the $\mathrm{Li}$ was finally transported from the $\mathrm{LiAlO}_{2}$ towards the $\gamma-\mathrm{Al}_{2} \mathrm{O}_{3}$; this resulted in a $\mathrm{Li}$ content of about $0.35 \mathrm{wt} . \%$ and a $\mathrm{K}$ content of about $12.3 \mathrm{wt} . \%$. The loss of alkali on the way from the impregnated $\mathrm{LiAlO}_{2}$ to the $\gamma-\mathrm{Al}_{2} \mathrm{O}_{3}$ and the slow transport of the alkali mentioned above were probably caused by adsorption and reaction with the surrounding quartz tube and the alumina wool plugs used to support the grains of impregnated $\mathrm{LiAlO}_{2}$ and the adsorbent bed. Table 2 also shows that the addition of $\mathrm{CO}_{2}$ to the gas substantially retarded the rate of alkali transport as a consequence of lowering the partial pressures of the alkali hydroxides [10].

\subsection{Catalyst behaviour during the stability tests}

The steam-reforming activities of the catalysts were measured continuously during the stability tests and the results of the tests in which the gas flow of Set A was used are shown for a number of catalysts in Figs. 4-6. For reasons of

Table 2

Measured alkali contents in the $\gamma-\mathrm{Al}_{2} \mathrm{O}_{3}$ bed after different times of operation using different gas compositions

\begin{tabular}{|c|c|c|c|c|c|c|}
\hline \multirow{3}{*}{$\begin{array}{l}\text { Time on } \\
\text { stream } \\
\text { (h) } \\
\end{array}$} & \multicolumn{6}{|c|}{ Amounts of alkali (metal) present in the $\gamma-\mathrm{Al}_{2} \mathrm{O}_{3}$ grains (mg) } \\
\hline & \multicolumn{3}{|l|}{ Lithium } & \multicolumn{3}{|l|}{ Potassium } \\
\hline & $0 \% \mathrm{CO}_{2}{ }^{\mathrm{a}}$ & $0.5 \% \mathrm{CO}_{2}{ }^{\mathrm{a}}$ & $45 \% \mathrm{CO}_{2}{ }^{\mathrm{a}}$ & $\overline{0 \% \mathrm{CO}_{2}{ }^{\mathrm{a}}}$ & $0.5 \% \mathrm{CO}_{2}{ }^{\mathrm{a}}$ & $45 \% \mathrm{CO}_{2}{ }^{\mathrm{a}}$ \\
\hline 0 & $<0.01$ & $<0.01$ & $<0.01$ & $<0.01$ & $<0.01$ & $<0.01$ \\
\hline 10 & 0.01 & n.d. & n.d. & 0.42 & n.d. & n.d. \\
\hline 35 & 0.02 & $<0.01$ & n.d. & 1.49 & 0.28 & n.d. \\
\hline 88 & 0.35 & $<0.01$ & $<0.01$ & 7.35 & 0.25 & 0.14 \\
\hline 100 & 0.21 & n.d. & n.d. & 9.47 & n.d. & n.d. \\
\hline 161 & 0.29 & n.d. & n.d. & 10.6 & n.d. & n.d. \\
\hline
\end{tabular}

n.d.: not determined.

${ }^{a}$ Concentration of $\mathrm{CO}_{2}$ in the gas flow (for further details, see Section 2). 


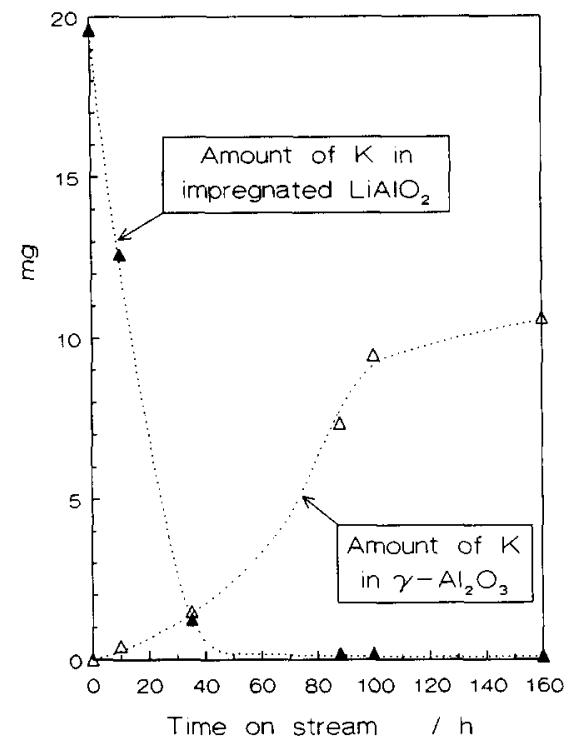

Fig. 3. Amount of $\mathrm{K}$ in the bed of impregnated $\mathrm{LiAlO}_{2}$ grains and that in the bed of $\gamma-\mathrm{Al}_{2} \mathrm{O}_{3}$ at the position of the catalyst during the stability test when the gas flow of Set $\mathrm{A}$, containing $0 \% \mathrm{CO}_{2}$, was used.

clarity and to make a clear distinction between the different curves presented in the figures, only a limited number of the measured points are shown for each catalyst. The numerical values of the initial and final activities of all the catalysts tested, as well as the observed weights before and after the tests, the

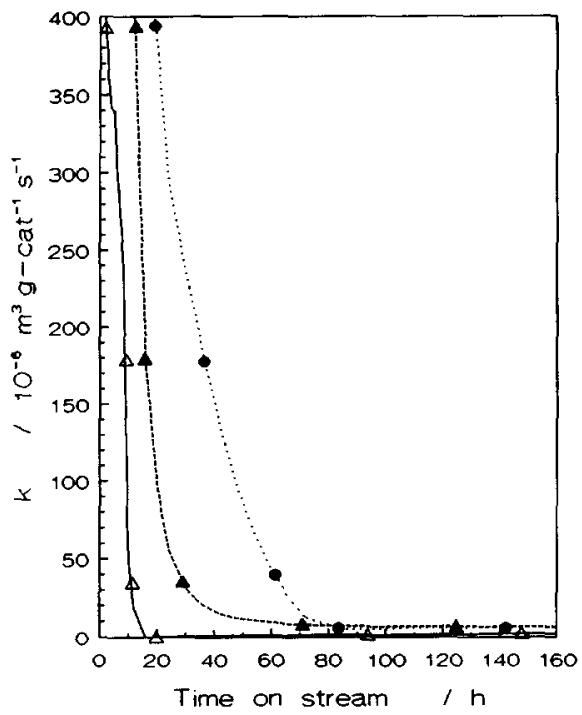

Fig. 4. Reaction rate coefficients of the impregnated catalysts as a function of time during the stability test using the gas flow of Set A: $(\triangle) \mathrm{I}-\alpha \mathrm{Al}, 80 \mathrm{mg},(\Delta)=\mathrm{I}-\alpha \mathrm{Al}, 160 \mathrm{mg},(\mathbf{O}) \mathrm{I}-\gamma \mathrm{Al}$. 


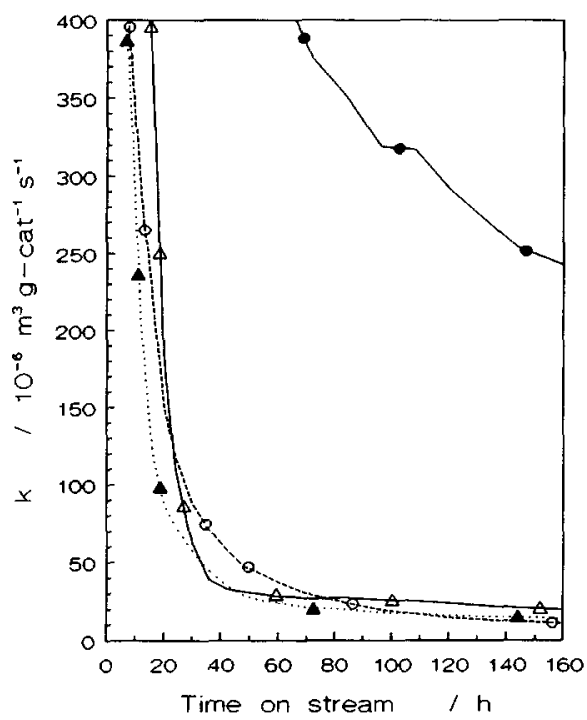

Fig. 5. Reaction rate coefficients of several coprecipitated catalysts as a function of time during the stability test using the gas flow of Set $\mathrm{A}:(\Delta) \mathrm{C}-\mathrm{Ni}_{3} \mathrm{Al},(\bigcirc) \mathrm{C}-\mathrm{NiAl}_{3},(\triangle) \mathrm{C}-\mathrm{NiAl}_{2} \mathrm{Mg},(\mathrm{O}) \mathrm{C}-\mathrm{NiAl}_{2.5} \mathrm{La}_{0.5}$.

estimated alkali contents after the test and the physical condition of the samples after the test are shown in Table 3.

Fig. 4 gives the performances obtained for the catalysts $\mathrm{I}-\alpha \mathrm{Al}$ and $\mathrm{I}-\gamma \mathrm{Al}$ prepared by impregnation of $\alpha-\mathrm{Al}_{2} \mathrm{O}_{3}$ and $\gamma-\mathrm{Al}_{2} \mathrm{O}_{3}$ respectively; both showed a

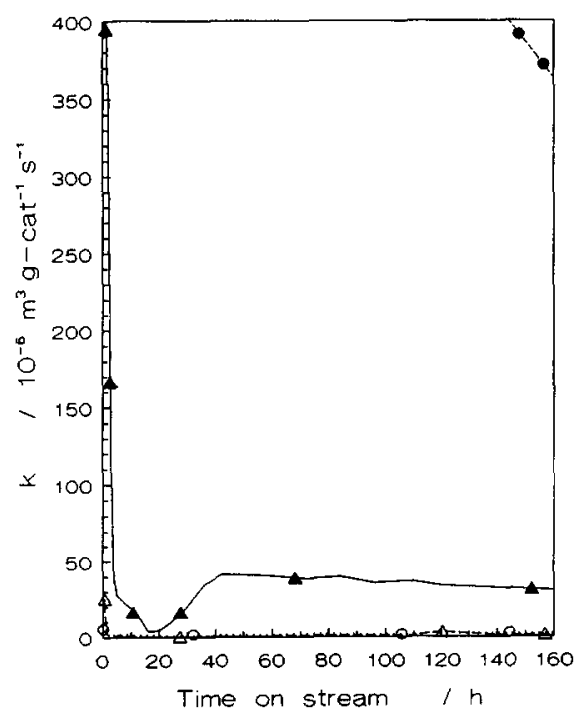

Fig. 6. Reaction rate coefficients of several other catalysts as a function of time during the stability test using the gas flow of Set A: (ム) C-NiMg $3,(\mathbf{O}) \mathrm{DP},(\mathrm{O}) \mathrm{NiO} / \gamma-\mathrm{Al}_{2} \mathrm{O}_{3}$ (see Note 6, Table 3), ( $\Delta$ ) Ni (see Note 7 , Table 3). 
Table 3

Characteristics of the catalysts after the stability test

\begin{tabular}{|c|c|c|c|c|c|c|c|c|c|}
\hline \multirow[t]{2}{*}{ Catalyst } & \multirow[t]{2}{*}{$\begin{array}{l}\mathrm{Ni} \\
\text { wt.\% }\end{array}$} & \multirow[t]{2}{*}{$\begin{array}{l}T_{\text {cal }} \\
(\mathbf{K})\end{array}$} & \multirow[t]{2}{*}{$\begin{array}{l}\text { Gas } \\
\text { flow a }\end{array}$} & \multicolumn{2}{|c|}{$\begin{array}{l}\text { Reaction rate } \\
\text { coefficients } \\
\left(\mathrm{m}^{3} \mathrm{~g}_{\text {cat }}^{-1} \mathrm{~s}^{-1}\right)\end{array}$} & \multirow[t]{2}{*}{$\begin{array}{l}\text { Weight } \\
\text { change } \\
(\%)\end{array}$} & \multicolumn{2}{|c|}{$\begin{array}{l}\text { Estimated }{ }^{\mathrm{d}} \\
\text { alkali content } \\
(\mathrm{wt} \% \text { ) }\end{array}$} & \multirow[t]{2}{*}{$\begin{array}{l}\text { Physical } \\
\text { condition } \\
\text { after the test }\end{array}$} \\
\hline & & & & Start ${ }^{b}$ & End ${ }^{c}$ & & $\mathrm{Li}$ & K & \\
\hline $\mathrm{I}-\alpha \mathrm{Al}$ & 14.7 & 873 & Set A & $9.1 \cdot 10^{-6}$ & $2.0 \cdot 10^{-6}$ & +14.8 & 0.24 & 8.6 & Top $30 \%$ sticky \\
\hline $\mathrm{I}-\alpha \mathrm{Al}, 160 \mathrm{mg}$ & 14.7 & 873 & Set A & $9.1 \cdot 10^{-6}$ & $6.1 \cdot 10^{-6}$ & +5.3 & 0.10 & 3.4 & Top $25 \%$ sticky \\
\hline $\mathrm{I}-\gamma \mathrm{Al}$ & 13.0 & 873 & Set A & $2.2 \cdot 10^{-5}$ & $6.7 \cdot 10^{-5}$ & +12.8 & 0.28 & 10.1 & Top $30 \%$ sticky \\
\hline $\mathrm{C}-\mathrm{Ni}_{3} \mathrm{Al}$ & 78.7 & 723 & Set A & $9.2 \cdot 10^{-5}$ & $1.4 \cdot 10^{-5}$ & -7.6 & $\mathrm{c}$ & e & Very sticky \\
\hline $\mathrm{C}-\mathrm{NiAl}_{3}$ & 26.8 & 873 & Set A & $8.7 \cdot 10^{-5}$ & $2.4 \cdot 10^{-4}$ & +0.2 & 0.07 & 2.6 & $\begin{array}{l}\text { Upper part } \\
\text { slightly sticky }\end{array}$ \\
\hline $\mathrm{C}-\mathrm{NiAl}_{2.5} \mathrm{La}_{0.5}$ & 18.6 & 873 & Set A & $3.1 \cdot 10^{-5}$ & $1.1 \cdot 10^{-5}$ & +14.3 & 0.30 & 10.8 & Slightly sticky \\
\hline $\mathrm{C}-\mathrm{NiAl}_{2} \mathrm{Mg}$ & 30.8 & 1073 & Set A & $4.6 \cdot 10^{-5}$ & $2.1 \cdot 10^{-5}$ & +7.7 & 0.21 & 7.5 & $\begin{array}{l}\text { Top } 20 \% \text { stuck } \\
\text { together }\end{array}$ \\
\hline $\mathrm{C}-\mathrm{NiMg}_{3}$ & 29.4 & 773 & Set A & $6.9 \cdot 10^{-6}$ & $3.1 \cdot 10^{-5}$ & -8.0 & e & c & Unchanged \\
\hline DP & 19.4 & 873 & Set A & $4.6 \cdot 10^{-5}$ & $3.6 \cdot 10^{-4}$ & +10.5 & 0.25 & 8.7 & Top 25\% sticky \\
\hline $\mathrm{NiO} / \gamma-\mathrm{Al}_{2} \mathrm{O}_{3}{ }^{\mathrm{f}}$ & 21.0 & - & Set A & $5.1 \cdot 10^{-6}$ & $2.0 \cdot 10^{-6}$ & +6.4 & 0.19 & 6.8 & Top $20 \%$ sticky \\
\hline $\mathrm{Ni}^{g}$ & 100 & 773 & Set A & $2.3 \cdot 10^{-4}$ & $0.9 \cdot 10^{-6}$ & -1.0 & & & $\begin{array}{l}\text { Single lump, } \\
\text { not sticky }\end{array}$ \\
\hline $\mathrm{C}-\mathrm{NiAl}_{2} \mathrm{Mg}$ & 30.8 & 1073 & Set $\mathrm{C}$ & $4.6 \cdot 10^{-5}$ & $1.1 \cdot 10^{-5}$ & -0.7 & 0.08 & 2.9 & Slightly sticky \\
\hline $\mathrm{DP}$ & 19.4 & 873 & Set C & $4.6 \cdot 10^{-5}$ & $3.5 \cdot 10^{-5}$ & -6.4 & & & Unchanged \\
\hline
\end{tabular}

a See Section 2.

b Reaction rate coefficients measured at $673 \mathrm{~K}$, taken from Ref. [24]; the values given for the samples $\mathrm{NiO} / \gamma-\mathrm{Al}_{2} \mathrm{O}_{3}$ and $\mathrm{Ni}$, however, were measured at $973 \mathrm{~K}$.

c Reaction rate coefficients measured at the end of the deactivation test.

d Due to the small amounts of material per sample, only the Li and $\mathrm{K}$ contents of some samples not included in this paper were determined by chemical analysis. From these results followed that the alkali contents of the samples shown in the table could be estimated reasonably from the weight changes observed by using four assumptions: (a) $\mathrm{Li}$ is present in the samples as $\mathrm{LiAlO}_{2}$ or $\mathrm{Li}_{2} \mathrm{O}$; (b) $\mathrm{K}$ is present as $\mathrm{KOH}$; (c) the $\mathrm{Li} / \mathrm{K}$ ratios are equal to those of the $\gamma-\mathrm{Al}_{2} \mathrm{O}_{3}$ samples used to determine the rate of alkali transport (Table 2); and (d) the samples with large surface areas $\left(S_{\mathrm{BET}}>50 \mathrm{~m}^{2} \mathrm{~g}^{-1}\right)$ lose $5 \%$ of their weight upon heating (due to loss of adsorbed water).

c These values are not shown because the estimation resulted in small negative alkali contents.

Physical mixture of $\mathrm{NiO}$ powder $(\mathrm{BDH})$ and $\gamma-\mathrm{Al}_{2} \mathrm{O}_{3}$ powder, isostatically pressed at 4000 bar and crushed and sieved to yield a particle size between 0.15 and $0.30 \mathrm{~mm}$.

\& Nickel obtained from nickel nitrate hexahydrate by calcination at $773 \mathrm{~K}$ and reduction at $673 \mathrm{~K}$, followed by sieving to yield a particle size between 0.15 and $0.30 \mathrm{~mm}$.

rather rapid decrease of the activity during the test. The catalyst I- $\gamma \mathrm{Al}$ deactivated less rapidly than the catalyst I- $\alpha \mathrm{Al}$, but its activity approached that of the latter after $80 \mathrm{~h}$. The influence of doubling the amount of catalyst was examined for the catalyst I- $\alpha \mathrm{Al}$. The period for which the activity was higher than $100 \cdot 10^{-6} \mathrm{~m}^{3} \mathrm{~g}_{\text {cat }}^{-1} \mathrm{~s}^{-1}$ was increased but there was only a slight increase in the final activity.

Fig. 5 shows that better results were obtained for the aluminium-containing coprecipitated catalysts. The catalyst $\mathrm{C}-\mathrm{NiAl}_{3}$ was more stable than the other coprecipitated catalysts, including $\mathrm{C}-\mathrm{NiMg}_{3}$ (Fig. 6). An increase of the nickel content or the addition of $\mathrm{La}$ or $\mathrm{Mg}$ thus apparently decreased the stability. A 
stability even better than that of $\mathrm{C}-\mathrm{NiAl}_{3}$ was found for the deposition-precipitation catalyst DP (see Fig. 6, after about $140 \mathrm{~h}$ of operation the activity dropped slowly below a value of $400 \cdot 10^{-6} \mathrm{~m}^{3} \mathrm{~g}_{\text {cat }}^{-1} \mathrm{~s}^{-1}$ ).

The $\mathrm{Ni} / \mathrm{MgO}$ catalyst showed an unusual behaviour during the stability test (see Fig. 6); after a very rapid deactivation over the first 10-20 h, the catalyst regained activity significantly over the following $20 \mathrm{~h}$ (to give a value of about $40 \cdot 10^{-6} \mathrm{~m}^{3} \mathrm{~g}_{\text {cat }}^{-1} \mathrm{~s}^{-1}$ ) and then gradually deactivated again. Fig. 6 also shows the results obtained for pure nickel and for a physical mixture of $\mathrm{NiO}$ and $\gamma-\mathrm{Al}_{2} \mathrm{O}_{3}$; both materials had a very low activity from the beginning of the test.

The final activities of most of the catalysts, given in Table 3, appear to be insufficient to allow them to be used in the IR-MCFC: a conservative value of the minimum steam-reforming activity required at $973 \mathrm{~K}$ was estimated to be $5.4 \cdot 10^{-5} \mathrm{~m}^{3} \mathrm{~g}_{\text {cat }}^{-1} \mathrm{~s}^{-1}$ under typical IR-MCFC operation conditions [23]. Only for the catalysts $\mathrm{C}-\mathrm{NiAl}_{3}$ and $\mathrm{DP}$ were the final reaction rate coefficients higher than the value minimum required for application in IR-MCFC.

Table 3 also shows some other characteristics of the catalysts after the tests. Due to the amounts of alkali taken up, the weight of the samples had usually increased. These weight increases are used to estimate the total alkali uptake of the catalyst, see Table 3 . The physical condition of the catalysts at the end of the tests is described briefly in the last column the table. In many cases, the upper part of the catalyst bed was sticky; this probably being caused by the adsorption of water vapour from the atmosphere on the $\mathrm{K}$ and/or Li species (presumably mainly $\mathrm{KOH}$ ); such species are hygroscopic and were probably present on the outer surface of the catalyst grains. It is likely that the sticky parts of the catalyst samples contained the main part of the alkali taken up; it thus appears that the majority of the alkali did not migrate through the whole catalyst bed in these cases. This was confirmed by the results of chemical analysis of the sticky upper part and the non-sticky lower part of the $\gamma-\mathrm{Al}_{2} \mathrm{O}_{3}$ sample removed from the reactor after $88 \mathrm{~h}$ on stream in the gas flow of set $\mathrm{A}$; the upper part contained $1.0 \mathrm{wt} . \% \mathrm{Li}$ and $20.2 \mathrm{wt} . \% \mathrm{~K}$ while the lower part only contained $0.03 \mathrm{wt} . \% \mathrm{Li}$ and $1.1 \mathrm{wt} . \% \mathrm{~K}$.

The relatively high residual activities for the catalysts $\mathrm{C}-\mathrm{NiAl}_{3}$ and $\mathrm{DP}$ suggest that these samples retained the alkali very strongly in the upper part of the bed, thus preventing poisoning of the lower part of these samples. The difference in stability found for these catalysts and that found for the impregnated $\mathrm{Ni} / \gamma-\mathrm{Al}_{2} \mathrm{O}_{3}$ catalyst can be explained by the higher resistance to sintering of the nickel crystallites in the catalysts $\mathrm{C}-\mathrm{NiAl}_{3}$ and $\mathrm{DP}$ due to the stronger nickel-support interaction arising from the preparation technique based on precipitation. The presence of magnesium and lanthanum oxide in the coprecipitated catalysts may have decreased the stability as a result of the interaction of these species with the alumina which results in turn in a weaker interaction with the alkali. Although the geometry of the reactor does not resemble the real MCFC configuration, it seems likely that a strong retention of the alkali on a 
small part of the catalyst will also enhance the stability of the catalyst under practical conditions.

The alkali content of the catalyst $\mathrm{C}-\mathrm{Ni}_{3} \mathrm{Al}$ after the test (see Table 3) was estimated to be negligible; however, the observation that the sample was very sticky after the test indicates that it must at least contain a small amount of alkali. A considerable proportion of the alkali thus migrated through the whole catalyst bed, thereby causing almost total deactivation. This also explains the weight increase of the alumina wool plug below this catalyst observed after the test and the fact that this plug was rather sticky after the test.

The unusual deactivation behaviour found for the $\mathrm{C}-\mathrm{NiMg}_{3}$ catalyst (Fig. 6) was probably caused by a very weak interaction of alkali with the $\mathrm{Ni}$ and $\mathrm{MgO}$, as indicated by the absence of any increase of weight of the catalyst during the deactivation test. The alkali probably migrated rapidly through the catalyst bed in the beginning of the test, thereby causing almost immediate deactivation of the catalyst and sintering of the $\mathrm{MgO}$; as the test progressed and the partial pressure of the alkali in the feed decreased, the rate of alkali transport out of the catalyst bed probably increased to such an extent that the alkali content of the catalyst bed started to decrease and the activity increased once more.

The two catalysts $\mathrm{C}-\mathrm{NiAl}_{2} \mathrm{Mg}$ and $\mathrm{DP}$ were also tested using a gas flow containing $45 \% \mathrm{CO}_{2}$. The activities of these two catalysts as a function of time are shown in Fig. 7; note that the scale of the time axis is larger than that in Figs. 4-6. Reaction rate coefficients higher than $115 \cdot 10^{-6} \mathrm{~m}^{3} \mathrm{~g}_{\text {cat }}^{-1} \mathrm{~s}^{-1}$ could not be measured because of approaching the steam-reforming equilibrium composition. The presence of $\mathrm{CO}_{2}$ clearly retarded the deactivation but it did

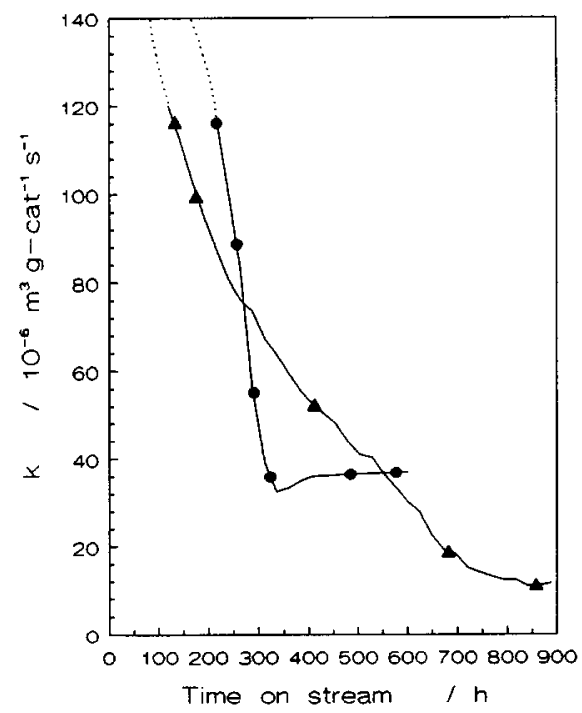

Fig. 7. Reaction rate coefficients of two catalysts as a function of time during the stability test using the gas flow of Set C, containing $45 \% \mathrm{CO}_{2}:(\Delta) \mathrm{C}-\mathrm{NiAl}_{2} \mathrm{Mg},(\mathbf{O}) \mathrm{DP}$. 
Table 4

Results of pre-test and post-test XRD analyses

\begin{tabular}{|c|c|c|c|c|c|}
\hline \multirow[t]{2}{*}{ Catalyst } & \multirow{2}{*}{$\begin{array}{l}\mathrm{Ni} \\
\text { wt. } \%\end{array}$} & \multirow{2}{*}{$\begin{array}{l}\text { Gas } \\
\text { flow }\end{array}$} & \multicolumn{2}{|c|}{$D_{\mathrm{Ni}}(\mathrm{nm})$} & \multirow[t]{2}{*}{ Other phases } \\
\hline & & & Pre-test & Post-test ${ }^{\mathrm{a}}$ & \\
\hline$[-\alpha \mathrm{Al}$ & 14.7 & Set A & 47 & U: n.d., L: $>100$ & $\mathrm{~L}: \alpha-\mathrm{Al}_{2} \mathrm{O}_{3}, \gamma-\mathrm{LiAlO}_{2}, \mathrm{X}^{\mathrm{h}}$ \\
\hline $\mathrm{I}-\alpha \mathrm{Al}, 160 \mathrm{mg}$ & 14.7 & Set A & 47 & $\mathrm{U}, \mathbf{L}:>100$ & $\mathrm{U}$ and $\mathrm{L}: \alpha-\mathrm{Al}_{2} \mathrm{O}_{3}, \mathrm{X}^{\mathrm{b}}$ \\
\hline $\mathrm{I}-\gamma \mathrm{A}]$ & 13.0 & Set A & 14 & $\mathrm{U}: \mathrm{n.d} . \mathrm{L}: 78$ & $\mathrm{~L}: \gamma_{-} \mathrm{Al}_{2} \mathrm{O}_{3}$ \\
\hline $\mathrm{C}-\mathrm{Ni}_{3} \mathrm{Al}$ & 78.7 & Set A & 12 & $>100$ & $X^{b}$ \\
\hline $\mathrm{C}-\mathrm{NiAl}_{3}$ & 26.8 & Set $A$ & 21 & $\sim 100$ & $\gamma-\mathrm{Al}_{2} \mathrm{O}_{3}, \mathrm{X}^{\mathrm{b}}$ \\
\hline C-NiAl ${ }_{2.5} \mathrm{La}_{0.5}$ & 18.6 & Set A & 7.8 & $\sim 100$ & $\mathrm{LaAlO}_{3}, \mathrm{X}^{b},\left(\mathrm{~K}_{2} \mathrm{CO}_{3} ?\right)$ \\
\hline $\mathrm{C}-\mathrm{NiAl}_{2} \mathrm{Mg}$ & 30.8 & Set A & 16 & U: n.d., L: 57 & $\mathrm{~L}: \mathrm{MgAl}_{2} \mathrm{O}_{4}, \mathrm{MgO}, \mathrm{X}^{\mathrm{b}}$ \\
\hline $\mathrm{C}-\mathrm{NiMg}_{3}$ & 29.4 & Set A & 12 & 76 & $\mathrm{MgO}$ \\
\hline $\mathrm{DP}$ & 19.4 & Set A & 18 & U: n.d., L: 90 & $\mathrm{L}: \gamma-\mathrm{Al}_{2} \mathrm{O}_{3}, \alpha-\mathrm{Al}_{2} \mathrm{O}_{3}$ (traces) \\
\hline $\mathrm{NiO} / \gamma-\mathrm{Al}_{2} \mathrm{O}_{3}$ & 21.0 & Set A & $>100$ & U: n.d., L: $>100$ & $\mathrm{~L}: \gamma-\mathrm{Al}_{2} \mathrm{O}_{3}, \mathrm{X}^{\mathrm{b}}$ \\
\hline $\mathrm{Ni}$ & 100 & Set $A$ & 76 & $>100$ & - \\
\hline $\mathrm{C}-\mathrm{NiAl}_{2} \mathrm{Mg}$ & 30.8 & Set $C$ & 16 & $\sim 90$ & $\mathrm{MgAl}_{2} \mathrm{O}_{4}$ \\
\hline DP & 19.4 & Set $C$ & 18 & 70 & $\gamma-\mathrm{Al}_{2} \mathrm{O}_{3}$ \\
\hline
\end{tabular}

n.d: not detected.

a $\mathrm{U}=$ upper part, $\mathrm{L}=$ lower part.

b Phase(s) with reflections at about $18.7^{\circ}, 20.3^{\circ}$ and $40.5^{\circ}$ (see text)

not decrease the extent of deactivation (see also Table 3). It thus appears that an atmosphere with only a low partial pressure of alkali can also deactivate the catalyst significantly, although it needs a longer period of time.

It should be noted that the water-gas shift equilibrium was always attained when the rates of the steam-reforming reaction were higher than $1 \cdot 10^{-5} \mathrm{~m}^{3}$ $\mathrm{g}_{\text {cat }}^{-1} \mathrm{~s}^{-1}$.

\subsection{Further characterisation of the deactivated catalysts}

The nature of the crystalline phases and the nickel crystallite sizes of the deactivated catalysts were determined by X-ray diffraction (XRD) and X-ray line broadening and the results are shown in Table 4.

The XRD patterns generally showed narrow nickel peaks due to large size of the nickel crystallites. The nickel crystallites of the nickel/alumina catalysts which did not contain a large amount of high-surface-area alumina (i.e. I- $\alpha \mathrm{Al}$, $\left.\mathrm{C}-\mathrm{Ni}_{3} \mathrm{Al}\right)$ sintered extensively. The catalysts containing magnesia $\left(\mathrm{C}-\mathrm{NiAl}_{2} \mathrm{Mg}\right.$ and $\mathrm{C}-\mathrm{NiMg}_{3}$ ) had smaller nickel crystallites after the test than had the other catalysts; however, these catalysts did not have the highest final activities. All the nickel crystallite sizes found after the test were significantly larger than those obtained after sintering in a steam-containing atmosphere without the addition of alkali vapour at $1073 \mathrm{~K}$ [24]; this indicates that alkali enhances sintering of the nickel crystallites much more strongly than does steam. Enhanced sintering of metal crystallites by the presence of alkali metal ions has 
been reported before. A well-known example is that of the K-promoted iron catalyst used for ammonia synthesis [25]. Enhanced sintering of the metal crystallites due to $\mathrm{Li}^{+}$and $\mathrm{K}^{+}$has also been observed for nickel catalysts supported on $\mathrm{SiO}_{2}$ [26] and $\mathrm{MgO}$ [27].

The deactivation test had little effect on the nature of the crystalline phases present in the catalysts in most of the samples. However, part of the alumina present in the $\mathrm{Ni} / \alpha-\mathrm{Al}_{2} \mathrm{O}_{3}$ catalyst had reacted to form $\gamma-\mathrm{LiAlO}_{2}$; the perovskite compound $\mathrm{LaAlO}_{3}$ had formed in the catalyst $\mathrm{C}-\mathrm{NiAl}_{2.5} \mathrm{La}_{0.5}$; and a small part of the $\mathrm{MgAl}_{2} \mathrm{O}_{4}$ of the $\mathrm{C}-\mathrm{NiAl}_{2} \mathrm{Mg}$ catalyst was dealuminised to give $\mathrm{MgO}$. The $\mathrm{MgO}$ of the catalyst $\mathrm{C}-\mathrm{NiMg}_{3}$ did not react with alkali; however, the alkali caused extensive sintering of the $\mathrm{MgO}$ crystallites, the average size had increasing from $12 \mathrm{~nm}$ to more than $200 \mathrm{~nm}$. Several samples also showed reflections which could not be assigned to known phases. The reflections at about $18.7^{\circ}, 20.3^{\circ}$ and $40.5^{\circ}$ appeared most frequently and were therefore assumed to arise from an unknown phase $X$. The absence of K-containing crystalline phases indicates the presence of one or more amorphous alkali-containing compound(s). It seems likely that alkali-containing phases had dissolved in water originating from the atmosphere prior to and during the XRD analysis.

Finally, the results of Table 4 also show that the milder but much longer stability test carried out using the gas flow containing $45 \% \mathrm{CO}_{2}$ caused about the same extent of sintering of the nickel crystallites but did not visibly affect the crystalline structure of the support.

The specific surface areas $\left(S_{\mathrm{BET}}\right)$ and pore volumes $\left(V_{\mathrm{p}}\right)$ of some of the catalysts were measured by nitrogen physisorption before and after the deactivation test and the results are shown in Table 5. In those cases that the gas flow of Set $A$ was used, both the surface area and the pore volume with pore radii smaller than $20 \mathrm{~nm}$ had decreased significantly. Comparable results were obtained for other catalysts not included in this paper [24]. Perrichon and Durupty [28] have also reported that the presence of alkali compounds enhances the sintering of catalyst support materials, such as $\mathrm{MgO}$ and, to a lesser extent $\gamma-\mathrm{Al}_{2} \mathrm{O}_{3}$, as well $\mathrm{SiO}_{2}$ and $\mathrm{Cr}_{2} \mathrm{O}_{3}$.

When aged with $45 \% \mathrm{CO}_{2}($ Set $\mathrm{C})$, the sintering of the $\gamma-\mathrm{Al}_{2} \mathrm{O}_{3}$ structure of

Table 5

BET surface areas and pore volumes of several catalysts before and after the stability test

\begin{tabular}{|c|c|c|c|c|c|c|}
\hline \multirow[t]{2}{*}{ Catalyst } & \multirow{2}{*}{$\begin{array}{l}\mathrm{Ni} \\
\text { wt. \% }\end{array}$} & \multirow{2}{*}{$\begin{array}{l}\text { Gas } \\
\text { flow }\end{array}$} & \multicolumn{2}{|l|}{ Pre-test } & \multicolumn{2}{|l|}{ Post-test $^{a}$} \\
\hline & & & $S_{\mathrm{BET}}\left(\mathrm{m}^{2} \mathrm{~g}^{-1}\right)$ & $\overline{V_{\mathrm{p}}\left(\mathrm{cm}^{3} \mathrm{~g}^{-1}\right)^{b}}$ & $S_{\mathrm{BET}}\left(\mathrm{m}^{2} \mathrm{~g}^{-1}\right)$ & $V_{p}\left(\mathrm{~cm}^{3} \mathrm{~g}^{-1}\right)^{b}$ \\
\hline $\mathrm{C}-\mathrm{NiAl}_{2.5} \mathrm{La}_{0.5}$ & 18.6 & Set $A$ & 166 & 0.36 & 7 & 0.02 \\
\hline DP & 19.4 & Set $A$ & 150 & 0.36 & U: n.d., L: 41 & U: n.d., L: 0.12 \\
\hline DP & 19.4 & Set $C$ & 150 & 0.36 & 105 & 0.32 \\
\hline
\end{tabular}

n.d. Not detected.

a $\mathrm{U}=$ upper part, $\mathrm{L}=$ lower part.

b Pore volume with pore radii smaller than $20 \mathrm{~nm}$. 
the DP catalyst was much less significant in spite of the fact that the final activity of this sample was much lower than when it was tested in the gas without $\mathrm{CO}_{2}$ (Set A). This indicates that the presence of $\mathrm{CO}_{2}$ prevents the formation of high concentrations of alkali compounds on the catalyst surface, thereby suppressing the affection of the $\gamma-\mathrm{Al}_{2} \mathrm{O}_{3}$ structure. However, the $\mathrm{CO}_{2}$ cannot prevent penetration through the whole catalyst bed by alkali compounds during several hundred hours.

TEM examinations of some samples of deactivated catalysts showed a rather wide distribution of nickel crystallite sizes; as well as relatively small crystallites, varying from ca. $10 \mathrm{~nm}$ (DP catalyst) to ca. $50 \mathrm{~nm}\left(\mathrm{C}-\mathrm{Ni}_{3} \mathrm{Al}\right.$ ), there were in most samples a small number of large nickel crystallites, varying from ca. 80 $\mathrm{nm}$ (DP catalyst) to more than $300 \mathrm{~nm}\left(\mathrm{C}-\mathrm{Ni}_{3} \mathrm{Al}\right)$ [24]. The crystallite sizes obtained from TEM were in reasonable agreement with those from X-ray line broadening given in Table 4; the differences probably arise from the fact that the results of X-ray line broadening give volume-averaged crystallite sizes in which large crystallites contribute strongly to the average size obtained.

TEM photographs of the sticky upper parts of several catalyst beds showed that these consisted mainly of particles totally covered with a glue-like layer, probably an alkali-containing compound. On the contrary, the alumina structure of the non-sticky lower parts of the catalysts $\mathrm{C}^{-\mathrm{NiAl}_{3}}$ and DP consisted of crystallites smaller than $10 \mathrm{~nm}$, as with the unused catalysts.

AES was applied to examine the outer surfaces several of the deactivated catalysts. For the catalyst $\mathrm{C}-\mathrm{Ni}_{3} \mathrm{Al}$, the outer surface contained mainly $\mathrm{K}, \mathrm{Al}$ and $\mathrm{O}$; the nickel content was very small and varied from place to place on the surface between 0 and $4 \%$. The composition of surfaces which had been formed by crushing this sample did not differ significantly from that of the outer surface, thus indicating that the $\mathrm{K}$ had penetrated throughout the grains. With the deactivated catalyst $\mathrm{C}-\mathrm{NiAl}_{3}$, which has a much higher alumina content than $\mathrm{C}-\mathrm{Ni}_{3} \mathrm{Al}$, the outer layer did not contain $\mathrm{Ni}$ since only $\mathrm{K}, \mathrm{Al}$ and $\mathrm{O}$ were observed. The nickel content was still unmeasurably small after etching for 6 min. When this sample was broken up, however, the surfaces exposed did not have such a nickel-free layer. This indicates that the $\mathrm{K}$ had probably not penetrated throughout the grains of this sample.

Hydrogen chemisorption was applied to several of the deactivated catalysts; however, the sensitivity of the measurement was too low to measure any adsorption of hydrogen which was probably a consequence of coverage of much of the surface of the nickel crystallites by a protective layer of alkali-containing compounds. Only the catalysts which had high steam-reforming activities after the deactivation test showed measurable hydrogen chemisorption; however, the average nickel crystallite sizes calculated from the amounts of hydrogen chemisorbed were still generally of one order of magnitude or more larger than those determined by X-ray line broadening.

The steam-reforming reaction rates of several of the deactivated catalysts 


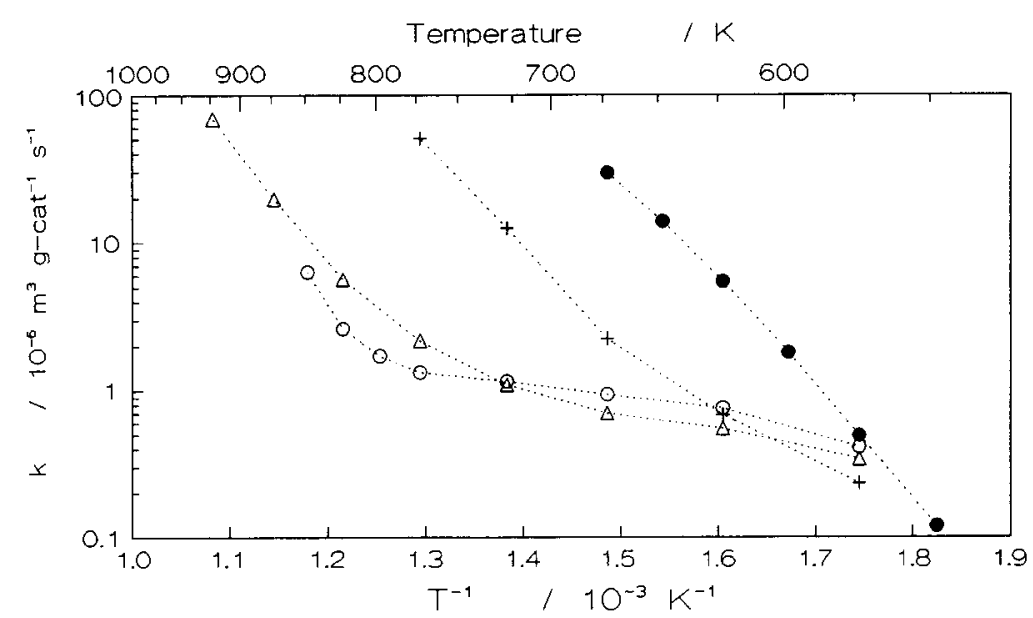

Fig. 8. Arrhenius plots of several catalysts (I): (O) C-NiAl ${ }_{2} \mathrm{Mg}$, fresh; (०) C-NiAl${ }_{2} \mathrm{Mg}$, post-test (Set A); (+) $\mathrm{C}-\mathrm{NiAl}_{3}$, post-test (Set $\left.\mathrm{A}\right) ;(\triangle) \mathrm{C}-\mathrm{NiMg}_{3}$, post-test (Set A).

were measured as a function of temperature. Arrhenius plots of some of the data obtained are shown in Figs. 8 and 9. For comparison, these figures also contain the results for two fresh samples, taken from Ref. [24].

The Arrhenius curves obtained for the post-test samples were very differently from those for the fresh samples, showing an apparent activation energy of ca. $140 \mathrm{~kJ} \mathrm{~mol}^{-1}$ with a slight decrease at higher temperatures which is probably due to the onset of diffusion limitation. Very low gradients (corresponding to apparent activation energies as low as $10 \mathrm{~kJ} \mathrm{~mol}^{-1}$ ), particularly at lower temperatures, were generally obtained, especially for those catalysts which had

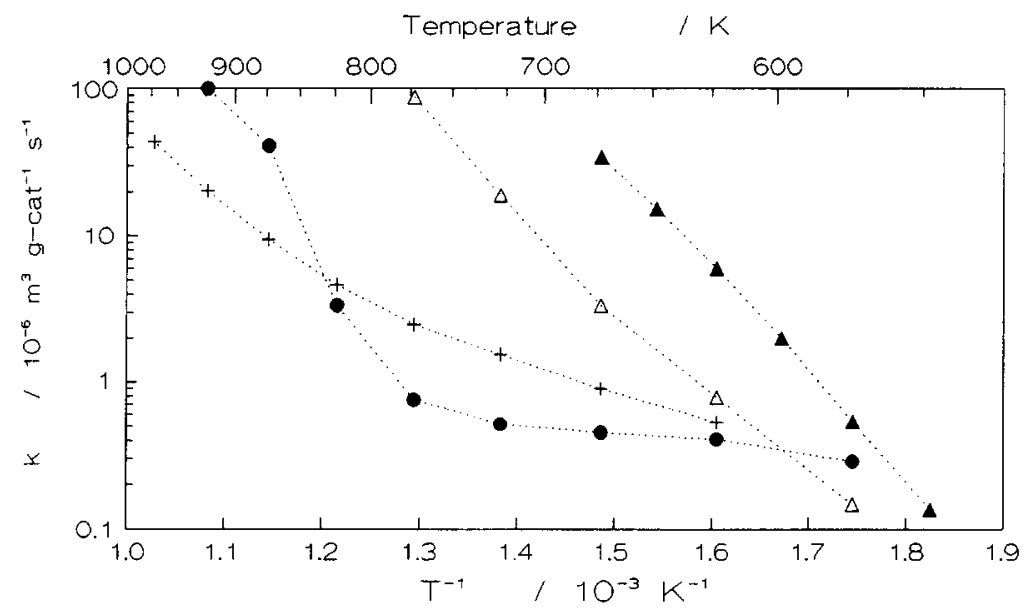

Fig. 9. Arrhenius plots of several catalysts (II): ( ) freshly reduced nickel sample prepared from nickel nitrate (see Table 3, Note 7); ( $\Delta$ ) DP, fresh; $(\triangle)$ DP, post-test (Set A); (+) DP after the test with $45 \% \mathrm{CO}_{2}$ in the gas flow (Set C). 
deactivated most strongly $\left(\mathrm{C}-\mathrm{NiAl}_{2} \mathrm{Mg}\right.$ and $\left.\mathrm{C}-\mathrm{NiMg}_{3}\right)$. However, the gradients were higher at higher temperature. As the data were reproducible on decreasing the temperature, it is unlikely that gradual removal of alkali species was responsible for the observed behaviour. Despite the fact that the samples had been stored in air for some time before the measurements, the activities at $973 \mathrm{~K}$ were close to those measured in the deactivation tests; this indicates that the behaviours shown in Figs. 8 and 9 were also not due to cooling to room temperature, exposure to air and reheating.

The relatively high gradients in the Arrhenius plots for the $\mathrm{C}-\mathrm{NiAl}_{3}$ and $\mathrm{DP}$ catalyst after the stability test using the gas flow of Set A suggests that at least a part of these catalyst beds had not been poisoned by alkali to any appreciable degree; this probably being the lower parts of the beds. This result suggests that the upper parts of the beds of these catalysts had been able to retain virtually all the alkali. More alkali probably moved further down in the DP catalyst bed during the $600 \mathrm{~h}$ test in the gas flow containing $45 \% \mathrm{CO}_{2}$, thus causing a more perceptible deactivation.

\section{General discussion}

The results obtained show clearly that the presence of alkali metal compounds caused significant deactivation of all the catalysts tested. Although the exact deactivation mechanism has not become clear, some tentative explanations can be given for several of the results found.

No satisfactory explanation has yet been given in literature for the sintering of alumina and magnesia in the presence of alkali compounds. Two processes might play a role.

(i) It is possible that alkali hydroxide (or alkali carbonate) adsorbs on the surface of the support (e.g. on the alumina) and has an effect similar to that of adsorbed $\mathrm{H}_{2} \mathrm{O}[24,29,30]$; both the alkali-hydroxide (or alkali-carbonate) species and the $\mathrm{H}_{2} \mathrm{O}$ molecule have a dipole moment and contain negatively charged oxygen. Because the alkali species are much more strongly adsorbed than is $\mathrm{H}_{2} \mathrm{O}$, the effect of alkali on the sintering may be much stronger.

(ii) When the surface of the catalyst is almost completely covered by adsorbed alkali, liquid phases may be formed. Such liquid phases would enhance sintering of the catalyst support by facilitating the transport of the ions from the support (e.g. $\mathrm{Al}^{3+}$ and $\mathrm{O}^{2-}$ ) by dissolution and re-precipitation.

It is not clear to what extent the nickel surface was covered by alkali species during the deactivation process. While there is strong deactivation of the catalysts and a large decrease of the amount of hydrogen that can be chemisorbed on the catalysts compared, there is relatively little growth of the nickel crystallites; this suggests that the surface of the nickel had become covered by other species. Although alkali compounds are more strongly adsorbed on metal oxide 
surfaces than on metal surfaces, several authors have reported that alkali ions also reside on metal surfaces. Significant amounts of monodispersed alkali (mostly K) species have been found on a nickel surface by Praliaud et al. [31,32] and by Bailey et al. [33]. Martin and Praliaud [34] have also concluded that a potassium silicate layer is present on the nickel surface of $\mathrm{K}$-promoted $\mathrm{Ni} / \mathrm{SiO}_{2}$ catalysts. The presence of alkali species on the metal itself has also been found for several other supported metal catalysts, such as $\mathrm{Rh}$ [35], $\mathrm{Ru}[36,37]$ and $\mathrm{Fe}$ [38-40]. In the present work, the AES results also indicate that a potassium (and lithium) aluminate-like layer on the nickel surface is well possible.

Besides covering the nickel surface to a large extent, the alkali may also influence the properties of the nickel, thus influencing the specific activity, the shape of the Arrhenius plots and/or the adsorption stoichiometry of hydrogen on the nickel. A decrease of the specific steam-reforming activity brought about by the presence of alkali has been observed by Rostrup-Nielsen $[41,42]$ and by Andrew [43]. Rostrup-Nielsen found that deactivation was more pronounced with catalysts based on the more alkali-resistant supports $\mathrm{MgO}$ and $\mathrm{MgAl}_{2} \mathrm{O}_{4}$, when compared with $\gamma-\mathrm{Al}_{2} \mathrm{O}_{3}$. In contrast, Parmaliana et al. $[27,44]$ did not find a decrease of the specific steam-reforming activity of a $\mathrm{Ni} / \mathrm{MgO}$ catalyst on addition of $\mathrm{Li}$ and $\mathrm{K}$.

A significant decrease of the specific activity of the methanation of $\mathrm{CO}$, i.e. the reverse of the steam-reforming reaction, due to the addition of alkali metal ions has been reported frequently [45-48]. The decrease of specific activity has been ascribed to electron donation from the alkali metal species to the nickel, thereby influencing the rates of the surface processes and/or the adsorption equilibria and/or the adsorption kinetics $[29,31,32,49,50]$.

Furthermore, the presence of alkali species has been found to decrease the adsorption enthalpy of electron-donating molecules such as hydrogen and methane and to increase the adsorption enthalpy of electron-withdrawing molecules such as $\mathrm{CO}$ by an electron enrichment of the metal [51-56]. This effect may be partially responsible for the decrease in the amounts of hydrogen which can be chemisorbed on the deactivated catalysts. Electron enrichment of the nickel may also cause stabilisation of adsorbed carbon [57,58]. Finally, in addition to influencing the adsorption characteristics of the nickel by electron enrichment, the alkali may also interact directly with adsorbed molecules and/or reaction intermediates [59].

A decrease of the steam-reforming activity as a consequence of a decrease of the rate of methane adsorption is plausible since several authors have reported that the (dissociative) adsorption of methane is the rate determining step (RDS) for the reaction (see e.g. the review by Ross [60]).

The non-linear form of the Arrhenius plots obtained for the deactivated catalysts could be caused by:

1. Change of the RDS as a function of temperature in the presence of alkali species. For example, if dissociative methane adsorption would become the 
RDS at lower temperature, it may explain the values of the apparent activation energies much lower than $140 \mathrm{~kJ} \mathrm{~mol}^{-1}$ which were found because the apparent activation energy for dissociative adsorption of $\mathrm{CH}_{4}$ on $\mathrm{Ni}(111), \mathrm{Ni}(110)$ and $\mathrm{Ni}(100)$ single crystal planes have been reported to be $40-50 \mathrm{~kJ} \mathrm{~mol}^{-1}[61-63]$. Another step may become rate determining at higher temperature.

2. Change of the distribution of alkali on the catalyst as a function of temperature. If the distribution of alkali species over the surface improves upon heating, diffusion limitation due to pore plugging may decrease. Another effect may be that if the alkali abandons a (small) proportion of the nickel surface upon heating, this surface would become available for steam reforming. Coverage of the external surface of the catalyst grains by a layer containing $\mathrm{K}, \mathrm{Al}$ and $\mathrm{O}$ and possibly also $\mathrm{Li}$ was found for the catalyst $\mathrm{C}-\mathrm{NiAl}_{3}$.

3. Preferential coverage of the most active sites of the nickel surface by alkali species, as found by Hoost and Goodwin, Jr. [64] for $\mathrm{K}$ added to a $\mathrm{Ru} / \mathrm{SiO}_{2}$ catalyst. This explanation is based on two observations: (i) the extensive and rapid deactivation during alkali ageing of a sample consisting of a physical mixture of $\mathrm{NiO}$ and $\gamma-\mathrm{Al}_{2} \mathrm{O}_{3}$ and of a sample of pure nickel (see Fig. 6), and (ii) the Arrhenius plot obtained for this pure nickel sample prior to the stability test (see Fig. 9), which also shows an increasing slope when going to higher temperatures. Because compounds such as metal oxides other than $\mathrm{NiO}$ were absent during the final stages of the production of the nickel oxide used for the physical mixture as well as in the preparation of the sample consisting of pure nickel, these samples probably only contained nickel crystallites larger than about $100 \mathrm{~nm}$. Such large nickel crystallites probably contain significantly fewer sites active for the various steps required for the steam-reforming reaction (e.g. the dissociative adsorption of the $\mathrm{CH}_{4}$ molecule) than do small nickel crystallites. Such active sites might occur on low coordination planes (other than $\mathrm{Ni}(111), \mathrm{Ni}(110)$ and $\mathrm{Ni}(100)$ ), steps and other irregularities on the surface (e.g. sites in the direct vicinity of species such as alumina). The small number of active sites of the samples only containing large nickel crystallites would thus have been poisoned rapidly by alkali and/or other adsorbed compounds and/or reaction intermediates. The less active sites which are not poisoned and which have higher activation energies for the various steps of the steam-reforming reaction will start to dominate the total reaction rate when the temperature is increased.

\section{Conclusions}

The following conclusions can be drawn from the stability tests and from the characterisation of the deactivated samples. 
1. The highest stabilities in an alkali-containing atmosphere were obtained for the coprecipitated nickel/alumina catalyst with high alumina content, C$\mathrm{NiAl}_{3}$, and for the deposition-precipitation catalyst, DP. The residual activities of these catalysts were sufficient for application in internal reforming in the MCFC. The high stability of these catalysts was probably caused by their ability to adsorb and retain the alkali very strongly.

2. Addition of $\mathrm{Mg}$ and $\mathrm{La}$ to the coprecipitated nickel/alumina catalyst decreased the stability; this was probably due to interaction of these compounds with the alumina, decreasing the interaction of the latter with the alkali.

3. Catalysts having a relatively weak interaction with the alkali $\left(\mathrm{Ni} / \alpha-\mathrm{Al}_{2} \mathrm{O}_{3}\right.$, $\mathrm{Ni} / \mathrm{MgO}$, and nickel/alumina samples with very high nickel contents) deactivated rapidly in an alkali-containing atmosphere; this was probably due to a rapid migration of the alkali through the whole catalyst bed.

4. Retardation of the supply of alkali to the catalyst by addition of $\mathrm{CO}_{2}$ to the gas also retarded the catalyst deactivation; however, the added $\mathrm{CO}_{2}$ only decreased slightly the extent of deactivation after a longer time of operation when approximately the same total amounts of alkali had been supplied to the catalyst as in the test without addition of $\mathrm{CO}_{2}$ to the gas.

5. The deactivation of the catalysts by alkali is likely to have been caused by the following phenomena:

- enhanced $\mathrm{Ni}$-crystallite growth to sizes of about $50-100 \mathrm{~nm}$ and larger;

- deactivation of the most active Ni sites by adsorption of alkali;

- chemical interaction of alkali with nickel and/or adsorbed species;

- sintering of the support materials, especially $\mathrm{MgO}$;

- chemical reaction with Al-containing support materials;

- coverage of a large part of the internal surface of the catalyst, followed by plugging of the pores by alkali compounds.

\section{Acknowledgements}

The authors thank $\mathrm{H}$. Weber for performing the chemical analyses and J. Boeijsma for performing the X-ray powder diffraction measurements. Thanks are also due to Dr. J. Beyer and M. de Groot from the Faculty of Mechanical Engineering of the University of Twente for carrying out the TEM experiments. Finally, the authors thank ECN for their financial support.

\section{References}

[1] J.H. Hirschenhofer, International Data Book on Fuel Cell Activities 1990 (Contract DE-AC01-88FE61684), Gilbert/Commonwealth, Inc., Reading, PA, USA.

[2] K. Ledjeff, T. Rohrbach and G. Schaumberg, Ber. Bunsenges. Phys. Chem., 94 (1990). 
[3] R.J. Selman, Molten Carbonate Fuel Cells (MCFC's) (DOE/ER/30060-T1), Energy (Oxford), 11 ( 1-2) (1986)

[4] K. Kishida, E. Nishayama, M. Matsumura, T. Tanaka, S. Kaneko, Y. Mori and S. Nakagawa, Extended Abstracts of the International Seminar on Fuel Cell Technology and Applications, 26-29 October 1987, Scheveningen, The Netherlands, p. 40.

[5] N. Giordano, F. Frustreri, P. Tsiakaras, A. Mezzapica and A. Parmaliana, Abstracts of the Fuel Cel] Seminar, 26-29 October 1986, Tuscon, p. 230.

[6] A. Parmaliana, F. Frustreri, P. Tsiakaras and N. Giordano, Adv. Hydrogen Energy, 5 (1986), (Hydrogen Energy Progr. 3), 1252.

[7] V.A. Sobanyin, I.I. Bodrova, E.Yu. Titova, O.V. Bazhan, V.D. Belyaev and N.N. Bodrov, React. Kinet Catal. Lett., 39 (1989) 443.

[8] M. Tarjanyi, L. Paetch, R. Bernard and H. Ghezel-Ayagh, Proceedings International Seminar on Fuel Cells, 1985, p. 177.

[9] K. Kishida, Ber. Bunsenges. Phys. Chem., 94 (1990) 941.

[10] R.J. Berger, E.B.M. Doesburg, J.G. van Ommen and J.R.H. Ross, J. Electrochem. Soc., submitted for publication.

[11] O. Ferreti, P. Marécot, M. Demicheli, G. Gonzalez, D. Duprez and J. Barbier, Bull. Soc. Chim. Fr., 127 (1990) 347.

[12] E.C. Kruissink, L.L. van Reijen and J.R.H. Ross, J. Chem Soc. Faraday Trans. I, 77 (1981) 649.

[13] H.G.J. Lansink Rotgerink, H. Bosch, J.G. van Ommen and J.R.H. Ross, Appl. Catal., 27 (1986) 41.

[14] H. Schaper, E.B.M. Doesburg, J.M.C. Quartel and L.L van Reijen, Stud. Surf. Sci. Catal., 16 (1983) 301.

[15] H. Schaper, D.J. Amesz, E.B.M. Doesburg, P.H.M. de Korte, J.M.C. Quartel and L.L. van Reijen, Appl. Catal., 16 (1985) 417.

[16] F.M. Dautzenberg, in S.A. Bradley, M.J. Gattuso and R.J. Bertolacini (Editors), Am. Chem. Soc. Symp. Series, 411 (1988, published 1989) 99.

[17] J.R. Rostrup Nielsen, in J.R. Anderson and M. Boudart (Editors), Catalytic Steam Reforming, Catalysis Science and Technology, 5 (1983).

[18] J.R.H. Ross and M.C.F. Steel, J. Chem. Soc. Faraday Trans. I, 69 (1973) 10

[19] M. Boudart, AIChE J., 18 (1972) 465.

[20] H.P. Klug and L.E. Alexander, X-ray Diffraction Procedures, John Wiley and Sons, New York, 1974, p. 635.

[21] J.W.E. Coenen, PhD Thesis, University of Delft, 1958.

[22] H.G.J. Lansink Rotgerink, PhD Thesis, University of Twente, 1988.

[23] Internal Communication with ECN (The Netherlands Energy Research Foundation).

[24] R.J. Berger, PhD Thesis, University of Twente, 1992.

[25] W.D. Mross, Catal. Rev. Sci. Eng., 25 (1983) 591.

[26] P. Moral, H. Praliaud and G.A. Martin, React. Kinet. Catal. Lett., 34 (1987) 1.

[27] A. Parmaliana, F. Arena, F. Frustreri, N. Mondello and N. Giordano, in C.H. Bartolomew and J.B. Butt (Editors), Proceedings 5th International Symposium on Catalyst Deactivation, Evanston IL, 1991, p. 230.

[28] V. Perrichon and M.C. Durupty, Appl. Catal., 42 (1988) 217.

[29] P.J. Anderson and P.L. Morgan, Trans. Faraday Soc., 60 (1964) 930.

[30] W.G. Schlaffer, C.R. Adams and J.N. Wilson, J. Phys. Chem., 69 (1965) 1530.

[31] V. Pitchon, P. Gallezot, C. Nicot and H. Praliaud, Appl. Catal., 47 (1989) 357.

[32] H. Praliaud, J.A. Delmon, C, Mirodatos and G.A. Martin, J. Catal., 97 (1986) 334.

[33] K.M. Bailey, T.K. Campbell and J.L. Falconer, Appl. Catal., 54 (1989) 159.

[34] G.A. Martin and H. Praliaud, Catal. Lett., 9 (1990) 151.

[35] S. Kesraoui, R. Oukaci and D.G. Blackmond, J. Catal., 105 (1987) 432.

[36] T.E. Hoost and J.G. Goodwin, Jr., J. Catal., 130 (1991) 283.

[37] D.O. Uner, M. Pruski, B.C. Gerstein and T.S. King, J. Catal., 146 (1994) 530.

[38] G. Connell and J.A. Dumesic, J. Catal., 92 (1985) 17.

[39] M. Weiss and G. Ertl, Stud. Surf. Sci. Catal., 11 (1982) 277.

[40] G. Ertl and N. Thiele, Appl. Surf. Sci., 3 (1979) 99.

[41] J.R. Rostrup-Nielsen, J. Catal., 31 (1973) 173.

[42] J.R. Rostrup-Nielsen, Steam Reforming Catalysts, Teknisk Forlag A/S (Danish Technical Press Inc.), Copenhagen, 1975 
[43] S.P.S. Andrew, Ind. Eng. Chem., Prod. Res. Dev., 8 (1969) 321.

[44] A. Parmaliana, F. Frustreri, F. Arena, N. Mondello and N. Giordano, Stud. Surf. Sci. Catal., 48 (1988) 739.

[45] A. Zeini-Isfahani, PhD Thesis, University of Bradford, 1975.

[46] T.K. Campbell and J.L. Falconer, Appl. Catal., 50 (1989) 189

[47] P. Schoubiye, J. Catal., 14 (1969) 238.

[48] M.R. Gelsthorpe, K.B. Mok and J.R.H. Ross, J. Mol. Catal., 25 (1984) 253.

[49] A. Cimono, M. Boudart and H. Taylor, J. Phys. Chem., 58 (1954) 796.

[50] R.W. Joyner, J. Chem. Soc. Faraday Trans., 86-15 (1990) 2675.

[51] H. Praliaud, J.A. Delmon, C. Mirodatos and G.A. Martin, J. Catal., 97 (1986) 344.

[52] J.A. Delmon and C. Mirodatos, J. Mol. Catal., 25 (1984) 161.

[53] R.W. Joyner, J. Chem. Soc. Faraday Trans., 86 (1990) 2675.

[54] A. Cimino, M. Boudart and H. Taylor, J. Phys. Chem., 58 (1954) 796.

[55] J.E. Müller, Chem. Phys. Solid Surf., 6 (Coadsorption, Promoters and Poisons) (1993) 29.

[56] H.P. Bonzel and G. Pirug, Chem. Phys. Solid Surf., 6 (Coadsorption, Promoters and Poisons) (1993) 51.

[57] K.M. Bailey, T.K. Campbell and J.L. Falconer, Appl. Catal., 54 (1989) 159.

[58] T. Mori, A. Miyamoto and N. Takahashi, J. Catal., 102 (1986) 199.

[59] G.A. Martin and H. Praliaud, Catal. Lett., 9 (1990) 151.

[60] J.R.H. Ross, in M.W. Roberts and J.M. Thomas (Editors), Surface and Defect Properties of Solids, Vol. 4. Specialist Periodical Report, The Chemical Society, London, 1974, p. 34.

[61] I. Chorckendorff, I. Alstrup and S. Ullmann, Surf. Sci., 227 (1990) 291.

[62] X. Jiang and D.W. Goodman, Appl. Phys. A, 51 (1990) 99.

[63] R.A. Campbell, J. Szanyi, P. Lenz and D.W. Goodman, Catal. Lett., 17 (1993) 39.

[64] T.E. Hoost and J.G. Goodwin, Jr., J. Catal., 130 (1991) 283. 